\title{
Six Sigma: The Time to Act is Now
}

\section{Charles L. Munson*}

Department of Operations Management, Washington State University, USA

\section{Editorial}

"Six Sigma" does this represent a revolution for operations management and industrial engineering, or is it simply a repackaging of concepts that have existed for decades? Firms profess to practice "Six Sigma Quality," and individuals may now receive green or black belt "Six Sigma Certifications." The Six Sigma consulting practice is booming, and several books covering some form of Six Sigma appear each year. But for all the hype, is something new truly happening?

The term Six Sigma is usually attributed to Motorola, which instituted its significant quality improvement overhaul in the 1980s. In a statistical sense, Six Sigma refers to a production process that produces fewer than 3.4 defects per million. More generally, the term focuses on applying tools to systematically reduce defects via a discipline called DMAIC [1]. The five-step discipline involves (1) defining the project's purpose, (2) measuring the process and collecting data, (3) analyzing the data, (4) improving the process, and (5) controlling the process to ensure continuation of top performance levels.

If one closely examines the practitioner books and the list of topics covered on the Six Sigma certification exams, it can be difficult to understand what differentiates it from the decades-old concepts of Total Quality Management (TQM). In the middle of the 20th century, W. Edwards Deming combined William Shewart's study of statistical process control with his own managerial quality management philosophies to begin what we think of as the modern approach to managing quality. While much of the rest of the world was rebuilding from the horrors or World War II, many American companies were enjoying a post-war economic boom and felt little pressure from foreign competition. As a result, few were interested in embracing the concepts of Deming, Joe Juran, and others. However, Deming found a captive audience in Japan, where managers were eager to rebuild, grow, compete internationally, and create long-run competitive advantage. The results were remarkable. Japanese firms became world leaders in industries such as automobiles and electronics. New products came out quicker, cheaper, and with higher quality than their American counterparts.

The Japanese added their own contributions to TQM, introducing concepts such as just-in-time production, Kaizen, poka-yoke, the Toyota Production System, and Taguchi's Total Quality Loss Function. Once Western firms picked up on the importance of TQM in the 1980s, "lean" became the hot buzzword. In fact, several book authors have attempted to combine lean with Six Sigma [3,6].

What sets Six Sigma apart from the previous versions of TQM? The biggest difference is the introduction of individual certification in Six Sigma. Now, finally, operations management and industrial engineering professionals have their own certification that in some ways resembles those for certified public accountants, certified financial analysts, and certified financial planners. This has produced a wave of interest from college students and practicing managers to our field. As Six Sigma certifications become even more widespread and even better known, the practices should become even more widely adopted, and the number of collegiate programs and majors should begin to grow. Already, some programs, such as the MBA program at Washington
State University at Tri-Cities, partner with industry to provide a track that enables students to earn Six Sigma certification-a very tangible resume item when those students hit the job market. Online options are available through several schools, including Villanova and Southern New Hampshire University. Professional organizations such as the Institute for Industrial Engineering now offer regular Six Sigma training.

There is currently no single standard Six Sigma certification, as various corporations and organizations offer green and black belts. Perhaps the best known certifications come from the American Society for Quality. Both belts require the candidate to pass a written exam and have relevant work experience. Seekers of black belts must also have completed two documented Six Sigma projects.

The certifications seem to be making a mark in industry. A quick search through Monster.com shows more than 1000 Six Sigma black belt jobs being advertised. As of April 2012, Salary.com reports the mean salary of Six Sigma black belt jobs as $\$ 87,902$.

Of all the terms that might become popular, it has been almost humorous to see one that includes a statistical concept rise to the top especially because so many college students abhor the topic of statistics in general. Nevertheless, the academic community in operations management and industrial engineering should be embracing this opportunity.While papers covering Six Sigma topics have been appearing in our research journals, the number of them seems small compared to the level of interest from industry in this topic. The "science" or mathematical rigor underlying Six Sigma is relatively low compared to many other areas of operations management and industrial engineering, such as inventory control. Consultants tend to provide most of the books on lean and Six Sigma, while academics have tended to focus on other areas. This could be a missed opportunity. Surely there are further advances that researchers can bring forth. As the corporate world begins to grumble in cases where Six Sigma does not instantly translate into higher profits $[2,4]$, the academic community can come to the rescue by developing more sophisticated yet practical techniques for managers while investigating and reporting the major long-term benefits. One possible avenue (of many) might be to determine how to apply Six Sigma tools within Scott Sampson's "Process-Chain Network Analysis," which is an innovative framework for addressing service operations [5].

*Corresponding author: Charles L. Munson, Department of Operations Management, Washington State University, USA, Tel: 50-93-35-30-76; Fax: 5093-35-38-57; E-mail: munson@wsu.edu

Received April 30, 2012; Accepted May 02, 2012; Published May 04, 2012

Citation: Munson CL (2012) Six Sigma: The Time to Act is Now. Ind Eng Manage 1:e105. doi:10.4172/2169-0316.1000e105

Copyright: (c) 2012 Munson CL. This is an open-access article distributed unde the terms of the Creative Commons Attribution License, which permits unrestricted use, distribution, and reproduction in any medium, provided the original author and source are credited. 
The time for academics to fully exploit the popularity of Six Sigma is now, before the concept is relegated to the business buzzword archives. This is a chance to recruit students like never before.

\section{References}

1. Heizer J, Render B (2011) Operations Management. (10thedn), Pearson.

2. Brian H, Brian G (2007) Six Sigma: So Yesterday? Business Week.
3. Martin JW (2006) Lean Six Sigma for Supply Chain Management. McGraw-Hill, New York.

4. Morris B (2006) New rule: Look out, not in. Fortune.

5. Scott E. Sampson (2012) Visualizing Service Operations. Journal of Service Research 1-17.

6. Wedwood ID, Wedwood I (2007) Lean Sigma: A Practitioner's Guide. Prentice Hall. 